\title{
Endemik Pilosella hoppeana subsp. lydia (Bornm.\& Zahn) Sell \& West (Asteraceae) taksonu üzerine morfolojik, anatomik ve karyolojik bir çalışma
}

\section{A Morphological, anatomical and caryological study on endemic Pilosella hoppeana subsp. lydia taxa (Bornm. \& Zahn) Sell \& West (Asteraceae)}

Hakan SEPET

Ahi Evran Üniversitesi, Mühendislik-Mimarlık Fakültesi, Çevre Mühendisliği Bölümü, Kırşehir, Türkiye

Eser Bilgisi / Article Info

Araştırma makalesi / Research article

DOI: 10.17474/artvinofd.303250

Sorumlu yazar / Corresponding author

Hakan SEPET

e-mail: hakansepet@gmail.com

ORCID: 0000000258419969

Geliş tarihi / Received

31.03.2017

Düzeltme tarihi / Received in revised form

18.08.2017

Elektronik erişim / Online available

21.09.2017

Anahtar kelimeler:

Anatomi

Morfoloji

Karyoloji

Pilosella hoppeana subsp. Iydia

Keywords:

Anatomy

Morphology

Karyology

Pilosella hoppeana subsp. Iydia

\begin{abstract}
Özet
Endemik Pilosella hoppeana subsp. Iydia (Bornm.\&Zahn) Sell\&West (1975) taksonuna ait bitki örnekleri doğal yayılış alanlarından biri olan Manisa, Spil Dağı'ndan 2013 yılında toplanmıştır. Taksonun rozet şeklinde tabanda bulunan yapraklarında yoğun bir örtü tüyü gözlenmiştir. Anatomik incelemelerde kökte radyal iletim demetlerinde ksilem elemanlarının floem elemanlarına göre büyük bir yer kaplamaktadır. Gövdede yoğun tüylerin bulunduğu, kalın bir kutikula tabakasının epidermis hücrelerini örtmekte, iletim demetlerinin genelde bir büyük, bir küçük demet şeklinde diziliş göstermektedir. Yapraklar bifasiyal yaprak tipindedir ve buna bağlı olarak palizat parankiması ve sünger parankiması ayrımının net olarak gözlenmektedir. Abaksiyal yüzde daha uzun ve yoğun olmak üzere her iki yüzde de örtü ve salgı tüyleri ile belirli aralıklarla diziliş gösteren stoma hücrelerinin vardır. Stomalar abaksiyal yüzde üst durumludur. Taksonun yapılan karyolojik çalışmalarda kromozom sayısı $2 x=2 n=18$ olarak belirlenmiş, kromozom ölçümleri yapılmıştır.
\end{abstract}

\begin{abstract}
Plant samples of Endemic Pilosella hoppeana subsp. Iydia (Bornm. \& Zahn) Sell\&West (1975) the taxa were collected in 2013 from the Spil Mountain in Manisa, one of the natural spreading areas. A thick cover was observed on the leaves of the taxon rosette on the base. In the anatomical investigations, the radial transmission in the stem takes up a great deal of space in the bundles compared to the floem elements of the xylem elements. The body covers the epidermis cells of a thick capillary layer with dense fur, and the transmission bundles are generally arranged in a large, small bundle. The leaves are in the bifacial leaf type and accordingly the separation of palisade parenchyma and sponge parenchyma is clearly observed. The abaxial percentage is longer and more intense, and there are stoma cells that are arranged at regular intervals with cover and secretion feathers on both sides. Abdominal abdominal stomata is the upper case. The number of chromosomes was determined as $2 x$ $=2 n=18$ in karyological studies performed by Takson and chromosome measurements were made.
\end{abstract}

\section{Giriş}

$\mathrm{Bu}$ çalışmanın konusunu oluşturan Pilosella taksonu Asteraceae familyasına ait bir taksondur. Dünyanın en zengin familyalarından biri olan Asteraceae familyası 1156 tür ile Türkiye Florasının ikinci büyük familyasıdır ve filogenetik açıdan bu familyanın coğrafik kökeni Güney Amerika olarak kabul edilmektedir (Bremer 1996; Davis 1975). Pilosella cinsi Avrupa Florası'nda Hierecium cinsi içinde yer alırken, Türkiye Florası'nda ayrı bir cins olarak tanımlanmıştır ve Türkiyede 26 taksonla temsil edilmektedir. Pilosella cinsine ait türler genellikle eşeyli çoğalırlar, stolon bulundururlar, aken boyu $2,5 \mathrm{~mm}$ ve üstündedir, meyve sırt çizgileri hafif bir çıkıntı ile sonlanır, pappus tüyleri tek sıra halindedir (Sell 1987). Türkiye'deki
Pilosella türleri daha çok Kuzeydoğu Anadolu' da yayılış göstermektedir (Novak 1965).

Literatürde Pilosella cinsinde apomiksis ve buna bağlı olarak görülen poliploidi (Bicknell 1997) dışında bazı sitolojik (Bishop ve Davy 1994), ekolojik (William ve ark. 1987; Svavarsdo'ttır ve ark. 1999), anatomik ve tıbbi kullanım alanlarıyla ilgili çalışmalar da bulunmaktadır (Grieve 1995).

Bu çalışmanın amacı Pilosella hoppeana subsp. lydia (Bornm.\&Zahn) Sell\&West taksonunun morfolojik, anatomik ve karyolojik özelliklerini belirleyip türün tanıtımına katkıda bulunmaktır. 


\section{MATERYAL ve YÖNTEM}

Araştırmada kullanılan bitki örnekleri Türkiye' de B1 karesinde doğal yayılış gösterdiği yerlerden toplanmıştır (Çizelge 1, Şekil 2). Toplanan örneklerin bir kısmı morfolojik çalışmalarda kullanılmak üzere, standart herbaryum teknikleri kullanılarak kurutulmuştur(Şekil 3). Bu örnekler halen Celal Bayar Üniversitesi herbaryumunda saklanmaktadır. Toplanan örneklerin tür teşhisleri yaş ve kuru örnekler kullanılarak Davis (1975)' in "Flora of Turkey" adlı eserinin 5. cildinden yararlanarak yapılmıştır.



Şekil 1. Incelenen Türün Toplandığı Lokalite ( P. hoppeana subsp. lydia )

Çizelge 1. İncelenen Türün Toplandığı Lokaliteler

\begin{tabular}{llc}
\hline Takson & Lokalite & Tür Numarası \\
\hline P. hoppeana subsp. Iydia & Manisa Spil Dağı, At Alanı Mevkii, Orman altı, 25.07.2013 & HSEPET 185
\end{tabular}

Örneklerin kök, gövde ve yapraklarından alınan parçalar \%70' lik alkolde saklanmıştır. Bu örnekler sırasıyla önce alkol serilerinden geçirilmiş daha sonra anatomik çalışmalar için iki türün kök, gövde ve yapraklarından alınan parçalarla hazırlanan parafin bloklardan (Algan, 1981) kesit alındı ve bu kesitler safranin ve fast green boyalarıyla boyandı. Kesitlerden, Leica DM3000 motorize mikroskop kullanılarak fotoğraflar çekilmiştir. Elde edilen bulgular şekil ve çizelgeler halinde gösterilmiştir.

Sitolojik incelemeler taksonun tohumlarının çimlendirilmesi sonucu elde edilen kök uçları kullanılarak yapıldı. Bu çimlenen kök uçları önce $\alpha$ monobromonaftalin ile (16 saat) ön işleme tabi tutuldu sonra etanol ve asetik asit karışımı ile fiske edildi (24 saat). Kök uçları $1 \mathrm{~N} \mathrm{HCl}$ ile $60 \mathrm{C}$ de 15 dakika boyunca hidrolize tabi tutuldu ve Feulgen boyası ile 1 saat boyandı. Son olarak \%45 asetik asit ile ezildi (Elçi, 1994). Kromozomlar Leica DM3000 mikroskobu ile görüntülendi.

\section{MORFOLOJIK BULGULAR}

Stolonları az sayıda, kısa ve kalın bitkilerdir. Yaprakları çok sayıda olabilmektedir. Şekilleri oblanseolat ile oblong arasında değişir. Çok sayıda salgı özelliği olmayan tüylerin yanı sıra yaprak alt yüzünde yoğun, üst yüzünde ise nadir stellat tüylere sahiptir. Çiçeklenmiş gövdeler $40 \mathrm{~cm}$ kadar boylanabilmektedir. Yapraksızdır ve her birinde tek kapitulum vardır. Fillariler 6-14 x 1-3.5 mm ölçülerindedir. Dış taraftakiler ovattan linear lanseolata kadar değişen şekillere, iç taraftakiler ise lanseolattan, linear-lanseolata kadar değişen şekillere sahiptir. Birden yada yavaş yavaş 
daralırlar, uçları obtus veya subakut yapılıdır. Yoğun stellat tüylüdürler ve basit örtü tüyü veya salgı tüyü ya da her ikisine sahiptirler. Dış liguller genellikle dış taraflarında koyu kırmızı bir şeride sahiptir.

1. Yaprakların üst yüzü stellat tüysüz

2. İnvolukrum çok sayıda basit örtü tüyüne sahip, salgı tüyleri var ya da yok.
3. En içteki fillariler az çok akut, dıştakiler 1-2mm genişliğinde, lanseolat veya linear lanseolat şekillere sahip.

lydia

Takson 6-7. aylarda çiçeklenmektedir. Kayalık yokuşlarda bulunur, 100-2200 m arasında yayılış göstermektedir. Endemiktir.

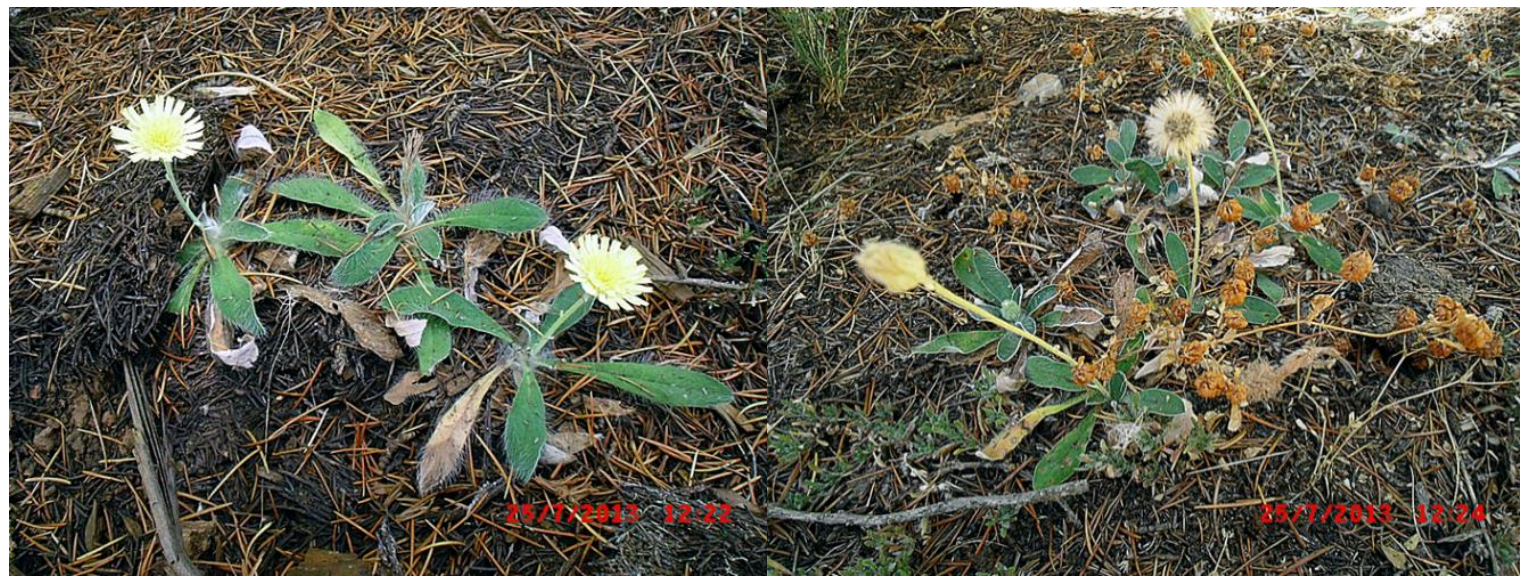

Şekil 2- P.hoppeana subsp. lyda nın Doğadaki görünüşü

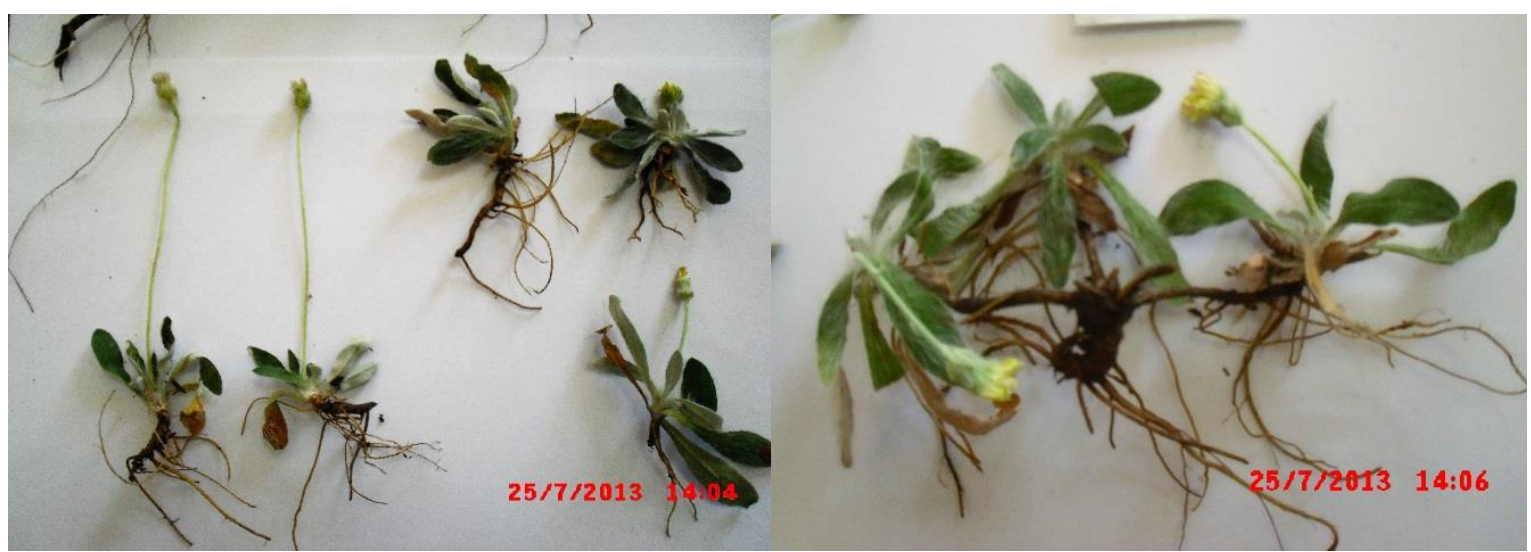

Şekil 3- P.hoppeana subsp. lyda nın Genel görünüşü

\section{ANATOMIK BULGULAR}

\section{Kök}

Kökten alınan enine kesite göre, kesit yuvarlak şekle sahiptir. En dışında tek sıralı, eni boyuna yakın ölçülere sahip epidermis tabakası bulunmaktadır. Bu tabakanın altında ise epidermise yakın birkaç sırası eni boyuna yakın hücrelerden oluşan 1-2 sıralı ekzodermis hücre tabakası mevcuttur. Sonraki hücre sıraları ise eni boyundan büyük hücrelerden oluşan korteks parankiması bulunmaktadır. Bu tabakayı bir sıralı, eni boyundan büyük hücrelerden oluşan endodermis tabakası takip etmektedir. Radyal iletim demetinin merkezini ksilem elamanları kaplamakta, ksilem kolları arasında ise floem hücreleri bulunmaktadır (Şekil 4, Çizelge 2).

\section{Skape}

Skape enine kesiti yuvarlaktır. En dışında kalın bir kutikula tabakası ile kaplı, tek sıralı, epidermis hücreleri bulunmaktadır. Bu hücrelerin farklılaşmasıyla oluşmuş çok sayıda stellat tüy kesit yüzeyini kaplamaktadır. Yüzeyde az sayıda salgı tüyüne de rastlanmıştır. Epidermisi takip eden ve hücre şekli bakımından epidermis hücrelerine benzeyen, yer yer 3 sıraya, bazen de tek sıraya kadar düşen, enleri ve boyları birbirine yakın ölçülere sahip korteks parankiması hücrelerini daha sonra 
çapları büyüyen ve farklı şekillere sahip korteks parankiması hücreleri takip etmektedir. Iletim demetleri bir büyük, bir küçük demetler şeklinde diziliş göstermektedir. Illetim demetlerinde ksilem elemanları baskındır. Floem elemanlarını çeperleri kalınlaşmış sklerankima hücreleri örtmektedir. Illetim demetlerini takip eden ve kesitin merkezini dolduran öz parankiması hücrelerinin çapları kesitin merkezinde en büyük ölçülere ulaşır iken iletim demetlerine yakın kısımlarda hücre çapları nispeten azalmaktadır(Şekil 4, Çizelge 2).



A

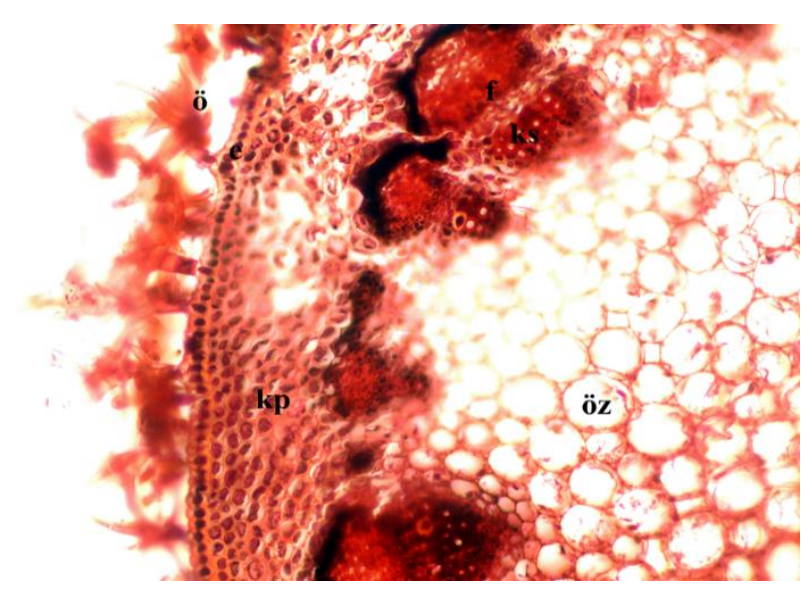

$\mathrm{B}$

Şekil 4- $P$. hoppeana subsp. lyda taksonunun anatomik fotografları A- Kök, B-Gövde, sa-salgı tüyü, ö-örtü tüyü, m- mezofil, f- floem ks- ksilem, enendodermis, öz- öz parankiması, i- iletim demeti

Çizelge 2. P. hoppeana subsp. lydia taksonunun çeşitli kısımlarının anatomik ölçüm değerleri

\begin{tabular}{|c|c|c|c|c|c|c|}
\hline & \multicolumn{3}{|c|}{ En } & \multicolumn{3}{|c|}{ Boy } \\
\hline & Min & Max & Ort \pm S.H. & Min & Max & Ort \pm S.H. \\
\hline \multicolumn{7}{|l|}{ Kök } \\
\hline Epidermis & 11.67 & 20.00 & $15.05 \pm 2.64$ & 5.00 & 11.67 & $8.45 \pm 2.21$ \\
\hline Korteks parankiması & 26.67 & 33.33 & $30.01 \pm 1.56$ & 8.33 & 30.00 & $20.94 \pm 7.86$ \\
\hline Endodermis & 8.33 & 13.33 & $10.87 \pm 1.64$ & 4.00 & 5.33 & $4.75 \pm 0.43$ \\
\hline Trake (Çap) & 6.67 & 26.67 & $17.26 \pm 6.86$ & & & \\
\hline Trakeitler (Çap) & 3.33 & 6.00 & $4.66 \pm 0.75$ & & & \\
\hline \multicolumn{7}{|l|}{ Gövde } \\
\hline Kutikula boyu & & & & 1.00 & 3.33 & $2.15 \pm 0.84$ \\
\hline Epidermis & 6.67 & 23.33 & $14.88 \pm 3.93$ & 8.33 & 13.33 & $10.40 \pm 1.77$ \\
\hline Korteks parankiması & 13.33 & 60.00 & $41.07 \pm 15.44$ & 6.67 & 30.00 & $19.68 \pm 7.55$ \\
\hline Floem sklerankiması(Çap) & 6.67 & 16.67 & $11.68 \pm 3.39$ & & & \\
\hline Ksilem hücreleri (Çap) & 6.00 & 17.00 & $11.86 \pm 3.68$ & & & \\
\hline Öz parankiması (Çap) & 10.00 & 60.00 & $36.08 \pm 16.85$ & & & \\
\hline \multicolumn{7}{|l|}{ Yaprak } \\
\hline Adaksiyal kutikula boyu & & & & 1.33 & 3.67 & $2.51 \pm 0.66$ \\
\hline Adaksiyal Epidermis & 13.33 & 40.00 & $27.76 \pm 7.88$ & 10.00 & 20.00 & $15.73 \pm 2.92$ \\
\hline Palizat parankiması & 10.00 & 19.00 & $14.30 \pm 3.17$ & 21.33 & 33.67 & $28.15 \pm 3.74$ \\
\hline Sünger parankiması & 10.00 & 16.67 & $13.37 \pm 2.14$ & 16.67 & 23.33 & $20.19 \pm 2.17$ \\
\hline Abaksiyal epidermis & 13.00 & 33.67 & $23.77 \pm 7.14$ & 10.00 & 20.67 & $14.90 \pm 3.60$ \\
\hline Abaksiyal kutikula boyu & & & & 1.00 & 3.33 & $2.24 \pm 0.69$ \\
\hline
\end{tabular}




\section{Yaprak}

Taksonun yaprak enine kesiti incelendiğinde kesitin adaksiyal ve abakasiyal yüzünü örten kutikula ile çevrilmiş, enleri genelde boylarından büyük, epidermis tabakası bulunmaktadır. Yaprağın her iki yüzünde de Ranunculus tip stomalar mevcuttur. Bu stomalar adaksiyal yüzde epidermis hücreleri ile aynı seviyede bulunur iken, abaksiyal yüzde epidermis hücrelerinden daha yukarıda üst durumlu olarak bulunmaktadırlar. Yaprağın her iki yüzünde de ama özellikle abaksiyal yüzünde oldukça uzun örtü tüyleri ve arasında ise salgı tüyleri mevcuttur. Epidermis tabakasının altında 2-5 sıralı boyları enlerinde büyük, bol kloroplast taşıyan palizat parankiması hücreleri bulunmaktadır. Abaksiyal yüzde ise enleri boylarından büyük ve hücreler arası boşlukları olan 3-4 sıralı sünger parankiması hücreleri vardır. Kesitte iletim demetleri etrafında demet kını hücreleri net seçilememektedir. Kesitin ana damarına yaklaşıldıkça palizat parankiması ve sünger parankiması ayrımı ortadan kalkmakta, hücreler yuvarlak parankimatik hücrelere dönüşmektedir(Şekil 5,Şekil 6, Şekil 7, Çizelge 2).

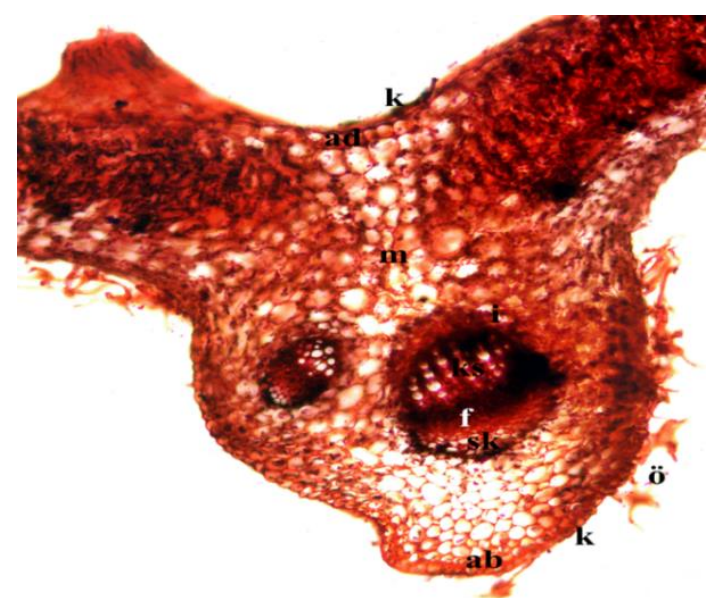

C



D

Şekil 5- $P$. hoppeana subsp. lyda taksonunun anatomik fotoğrafları, C,D-Yaprak, kesiti, k-kutikula, ad-adaksiyal epidermis, ab-abaksiyal epidermis, stsoma, p-palizat parankiması, s-sünger parankiması, sa-salgı tüyü, ö-örtü tüyü, m- mezofil, f- floem ks- ksilem, en- endodermis, öz- öz parankiması, iiletim demeti, sk-sklerankima

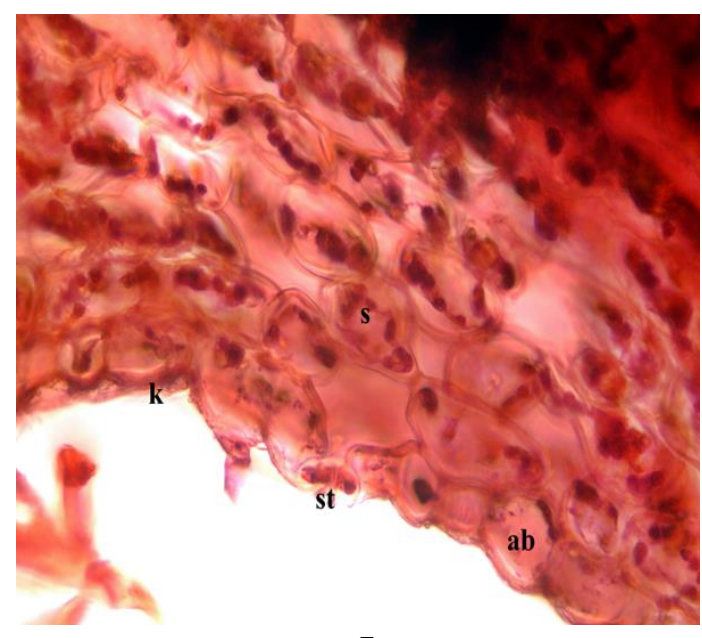

E

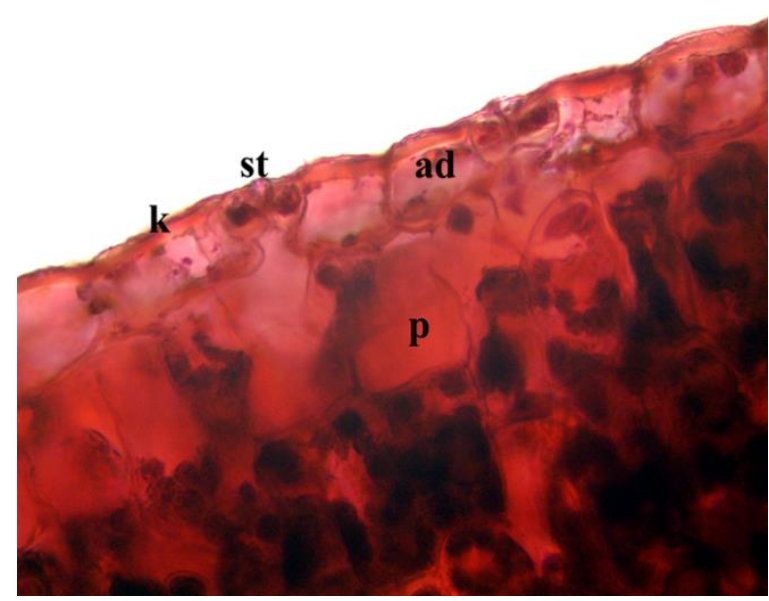

$\mathrm{F}$

Şekil 6- P. hoppeana subsp. lyda taksonunun anatomik fotografları E- Yaprak abaksiyal kesiti, F-Yaprak adaksiyal kesiti, k-kutikula, ad-adaksiyal epidermis, ab- abaksiyal epidermis, st-soma, 


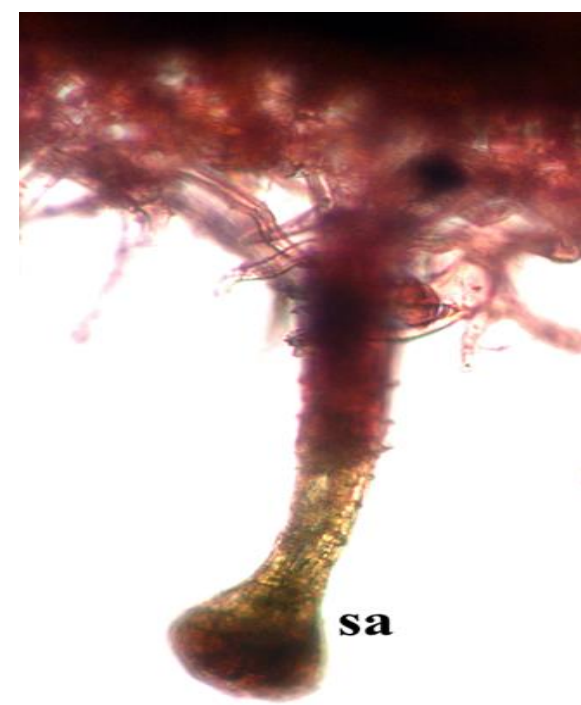

G

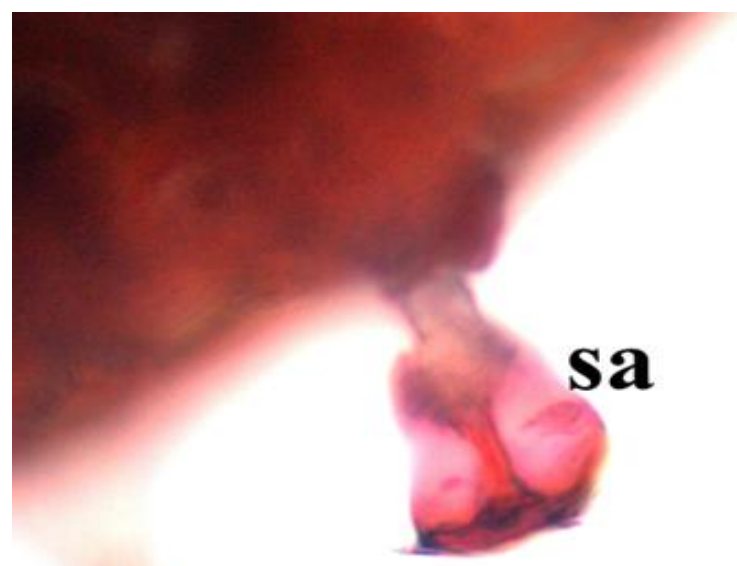

$\mathrm{H}$

Şekil 7- P. hoppeana subsp. lyda taksonunun anatomik fotoğrafları G-H Yaprakta salgı tüyleri sa- salgı tüyü

\section{SITOLOJIK BULGULAR}

Elde edilen kromozom örnekleri metafaz sashasında fotoğraflanmış ve idiogramları çizilmiştir (Şekil 8, Şekil 9). Taksonun kromozom sayısı yapılan incelemeler sonucunda $2 n=18$ ve temel sayı $x=9$ olarak tespit edilmiştir. Karyolojik bulgularda en uzun kromozom 4.37 $\mu \mathrm{m}$ en kısa kromozom $2.57 \mu \mathrm{m}$ olarak tespit edilmiştir. Üç numaralı kromozom Çiftinde satelit tespit edilmiştir. Kromozomlarda sentromer pozisyonu altı numaralı kromozom haricinde median bölgeli yapıda olup altı numaralı kromozomda sub median kromozom belirlenmiştir. Kromozomların nispi uzunlukları ve sentromer indeksleri hesaplanmış olup; kısa kol, uzun kol, kol oranı, kromozom uzunluğu ve sentromer pozisyonu ile birlikte çizelge halinde verilmiştir (Çizelge 3).

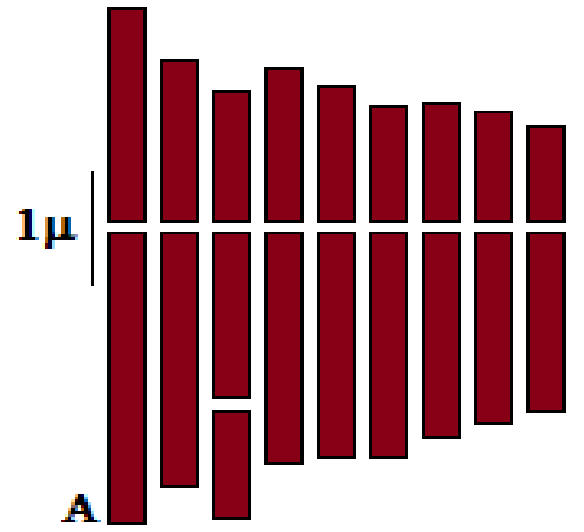

Şekil 8- P. hoppeana subsp. lyda taksonunun Haploid idiogramı

Çizelge 3. P. hoppeana subsp. Iydia Taksonunun Mitotik metafaz kromozom parametreleri

\begin{tabular}{|c|c|c|c|c|c|c|c|c|}
\hline Krmzm no & Krmzm boyu & Uzun kol & Kısa kol & Kol oranı & Sentromer indeksi & Nispi uzunluk & Sentromer pozisyonu & satellit \\
\hline 1 & 4.37 & 2.51 & 1.86 & 1.35 & 6.20 & 14.57 & $\mathrm{~m}$ & \\
\hline 2 & 3.73 & 2.19 & 1.54 & 1.42 & 5.13 & 12.43 & $\mathrm{~m}$ & \\
\hline 3 & 3.64 & 1.44 & 1.26 & 1.14 & 4.20 & 12.13 & $\mathrm{~m}$ & 0.94 \\
\hline 4 & 3.47 & 2.00 & 1.47 & 1.36 & 4.90 & 11.57 & $\mathrm{~m}$ & \\
\hline 5 & 3.30 & 1.97 & 1.33 & 1.48 & 4.43 & 11.00 & $\mathrm{~m}$ & \\
\hline 6 & 3.13 & 1.97 & 1.16 & 1.70 & 3.86 & 10.43 & sm & \\
\hline 7 & 2.97 & 1.80 & 1.17 & 1.54 & 3.90 & 9.90 & $\mathrm{~m}$ & \\
\hline 8 & 2.82 & 1.68 & 1.14 & 1.47 & 3.80 & 9.40 & $\mathrm{~m}$ & \\
\hline 9 & 2.57 & 1.57 & 1.00 & 1.57 & 3.33 & 8.57 & $\mathrm{~m}$ & \\
\hline
\end{tabular}

Total kromozom uzunluğu: $30.00 \mu \mathrm{m}$ 


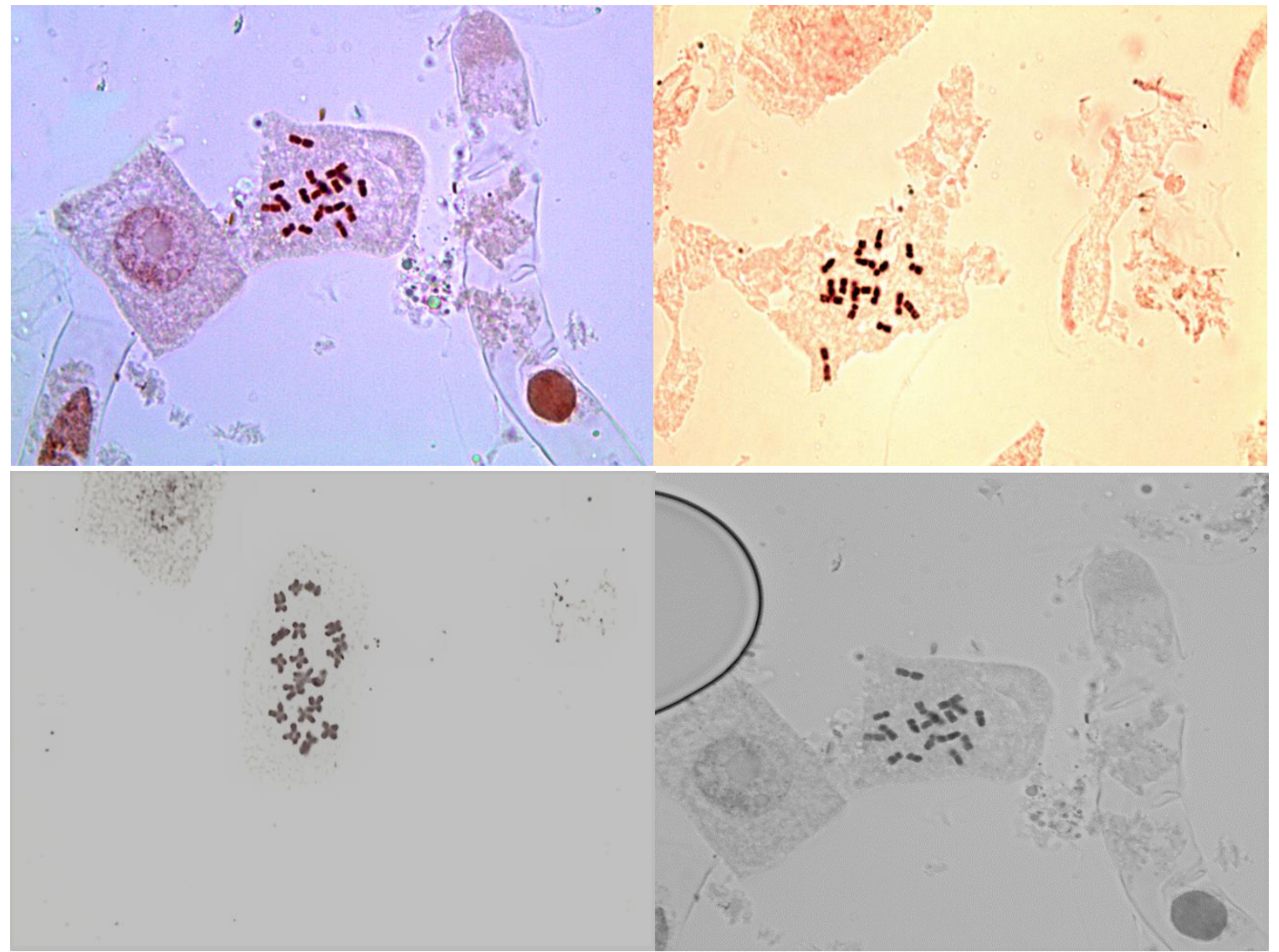

Şekil 9- $P$. hoppeana subsp. Iyda taksonunun Somatik metafazların mikrofografları

\section{TARTIŞMA VE SONUÇ}

Bu çalışmanda $P$. hoppeana subsp. Iydia taksonu morfolojik, anatomik ve karyolojik özellikleri bakımından incelenmiştir. Taksonun kökünde epidermis tabakasının altındaki ekzodermis tabakası yapılan diğer çalışmalarda P.officinarum, P.bauhini, P.hypeuryum, ve P.densiflora taksonlarında da gözlenmiştir. Bu çalışmada skapede gözlenen ve iletim demetlerindeki floem hücrelerini örten sklerankima hücreleri yukarıda adı geçen 4 taksonda da gözlenmiştir. Çalışmamızda ki taksonun bifasiyal yaprak yapısı ve yoğun örtü tüyleri adı geçen taksonlarda da bulunmaktadır (Umdu 2000). Yapılan bir çalışmada Asterasea familyasından bazı taksonların antioksidan aktivitelerini araştırılmıştır (Bakar ve ark. 2015). Bir başka çalışmada pilosellanın uçucu yağının kimyasal bileşimi, antimikrobiyal ve biyoaktif özellikleri çalışılmıştır (Üçüncü ve ark. 2015). Yapılan bazı çalışmalarda çeşitli bölgelerin flora özellikleri araştırılmış ve bitki dağılımları belirlenmiştir. Bu çalışmalarda pilosella taksonlarınada rastlanılmıştır (Kargıoğlu ve ark. 2007; Bräutıgam ve Greuter 2007; Cansaran ve ark. 2010). Bir başka çalışmada
Pilosella hoppeana nın morfolojik ve genetik çeşitliliği hakkında çalışılmıştır (Di Grıstına ve ark. 2013). Yapılan diğer bir çalışmada Sicilya için yeni bir tür tanımlaması yapılmıştır (Di Grıstına ve ark. 2016).

\section{Pilosella officinarum ve P.officinarum subsp. micradenium} F. W. Schultz \& Schultz-Bip., taksonlarında temel kromozom sayısının $x=9$ ve kromozom sayısı $2 n=18$ olarak tespit edilmiştir (Sell, 1987). Krahulcová ve arkadaşlarının yaptıkları çalışmada Pilosella cinsinden bazı taksonların poliploidi seviyeleri tespit edilmiştir. IInıckı ve Szeląg'in (2011) yaptıkları çalışmada $P$. aurantiaca (L.) F. W. Schultz \& Schultz- Bip.; $2 n=3 x=27$, P. fusca (Vill.) Arv.-Touv.; $2 n$ $=4 x=36$, $P$. fusca subsp. subpedunculata (Zahn) Szeląg, comb. nova; $2 \mathrm{n}=5 \mathrm{x}=45, P$. hoppeana subsp. testimonialis (Peter) Sell \& West; $2 n=2 x=18, P$. officinarum F. W. Schultz \& Schultz-Bip.; $2 n=6 x=54, P$. petraea F. W. Schultz \& Schultz-Bip.; $2 \mathrm{n}=2 \mathrm{x}=18, P$. rothiana (Wallr.) F. W. Schultz \& Schultz- Bip.; $2 n=4 x=$ 36, P. sabina F. W. Schultz \& Schultz-Bip.; $2 n=4 x=36, P$. ullepitschii (Błocki) Szeląg; $2 \mathrm{n}=2 \mathrm{x}=18$ olarak belirlemiştir. Yapmış olduğumuz bu çalışmada 
P.hoppeana subsp. lyda taksonu için de temel sayı $\mathrm{x}=9$ ve kromozom sayısı $2 \mathrm{n}=18$ olarak tespit edilmiştir. Karyolojik bulgularda en uzun kromozom $4.37 \mu \mathrm{m}$ en kısa kromozom $2.57 \mu \mathrm{m}$ olarak tespit edilmiştir. Üç numaralı kromozom Çiftinde satelit tespit edilmiştir. Kromozomlarda sentromer pozisyonu altı numaralı kromozom haricinde median bölgeli yapıda olup altı numaralı kromozomda sub median kromozom belirlenmiştir. Taksonun anatomik ve karyolojik çalışması ilk defa bizim tarafımızdan yapıımıştır. Takson endemik bir alt tür olup Türkiye Florasına göre Türkiye genelinde sadece üç bölgede yer almaktadır. Bu sebeple taksonun aşırı otlatma ve tahribatlara karşı koruma altında tutulması sağlanabilir.

\section{KAYNAKLAR}

Algan G (1981) Bitkisel Dokular İçin Mikroteknik. Fırat Üni. Fen Ed. Fak. Yayını, No:1, İstanbul

Bakar F, Bahadır AÖ, Ergene B, Nebioğlu S, Saltan ÇG (2015) Antioxidant Activity and Phytochemical Screening of Some Asteraceae Plants Turk J Pharm Sci 12(2), 123-132,

Bicknell RA (1997) Isolation of a diploid, apomictic plant of Hieracium auranticum, Sexual Plant Reproduction, Abstract Volume 10, Issue 3, 168-172

Bishop GF, Davy AJ (1994) Hieracium pilosella L. (Pilosella oficinarum F. Schultz\&Schultz-Bip.), Journal of Ecology, 82, 195-210

Bräutıgam S, Greuter W (2007) new treatment of Pilosella for the EuroMediterranean flora. Willdenowia 37 123-137

Bremer K (1996) Major clades and grades of the Asteraceae.In: Hind DJN, Beentje HJ ed (s). Compositae: systematics. Proceedings of the International Compositae Royal Botanic Gardens, Kew Volume 1.pp.1-7 -ISBN 0947643982

Cansaran C, Kaya ÖF, Ertekin AS, Ketenoğlu O (2010) A phytosociological study on Karaömer Mountain of North Anatolia (Amasya, Turkey) Acta Bot. Gallica, 157 (1), 65-88,

Davis PH (1975) Flora of Turkey and The East Aegean Islands Vol. 5, University Press Edinburgh
Di Grıstına E, Domına G, Gottschlıch G, Mazzola P, Geracı A (2013) Morphological and genetic diversity within Pilosella hoppeana aggr. (Asteraceae) in Italy and taxonomic implications Plant Biosystems, Vol. 147, No. 3, 788-799

Di Gristina E, Gottschlich G, Raimondo FM (2016) Pilosella hoppeana subsp. sicula Di Grist., Gottschl. \& Raimondo (Asteraceae), a new endemic subspecies from Sicily (Italy) Candollea, 71(1):7-12.

Elçi Ş (1994) Sitogenetikte araştırma yöntemleri ve gözlemler. 100. Yıl Üniversitesi Yayınları, No:18, Van

Grieve M (1995) A Modern Herbal, Elektric Newt, New York Vol 1

Ilnicki T, Szeląg Z (2011) Chromosome Numbers In Hieracium And Pilosella (Asteraceae) From Central And Southeastern Europe, Series Botanica 53/1: 102-110,

Kargıoğlu M, Cenkli S, Dayan S (2007) Endemic Plant Species and Their Threatened Categories Vegetated in The Boundary of Afyonkarahisar Province in Turkey. AKU Journal of Science 7(1) 287-311

Krahulcová A, Vladimirov V, Krahulec F, Bräutigam S (2009) The agamic complex of Pilosella (Asteraceae) in Bulgaria and SW Romania: variation in ploidy level and breeding systems Phytologia Balcanica Sofia. 15 (3): $377-384$

Novak FA (1965) Das Grobe Bilderlexikon der Pflanzen, Phonoklub No: 43 Stutgart

Sell PD (1987) An Introduction to the study of the British Hieracia, 1. History and classidication, Watsonia,16, 365-371

Svavarsdo'ttır K, Palmer JG, White JH (1999) Distrubition of three Hieracium species in the Mt Possession area, mid Canterbury, New Zealand, New Zealand Journal of Botany, Vol.37, 469-47

Umdu Ü (2000) Bazı Pilosella Hill (Compositae) Türlerinin Morfolojik ve Anatomik Yönden İncelenmesi. Karadeniz Teknik Üniversitesi, Fen Bilimleri Enstitüsü,Yüksek Lisans Tezi, 39 sayfa

Üçüncü O, Baltacı C, İlter ŞM, Gültepe M (2015) Pilosella hoppeana subsp. troica Bitkisinin Uçucu Yağının Kimyasal Bileşimi, Antimikrobiyal ve Biyoaktif Özelliklerinin İncelenmesi, 3.ilaç Kimyası: İlaç Etkin Maddesi Tasarımı, Sentezi, Üretimi ve Standardizasyonu Kongresi P.207

William GL, Johnstone RD, Craw D (1987) Arsenic consentrations in Hiracium pilosella (Compositae), Plant Syst., Evol., 157, 219-245 